\title{
PROLEGOMENON FOR AN ETHICS OF VISIBILITY IN HANNAH ARENDT*
}

Bethânia Assy ${ }^{* *}$

\begin{abstract}
This paper aims to discuss the Arendtian notions of appearance and perception in order to promote a displacement of those conceptions from the generally associated domain of passive apprehension of the faculty of knowledge towards the domain of a praxiology of action and language, based on an active perception. Arendt's appropriations on the Heideggerian "to take one's <it> place" (sich hin-stellen) will be discussed, as well as the Augustinian "finding oneself in the world" (diligere). A twofold disposition of appearance will be distinguished: producing and position, whose transposed to the Arendtian notion of world correspond, respectively, to fabrication (poiessis) of the world, man's objective in-between space, and to action (praxis) in the world, man's subjective in-between space. Those conceptual replacements, in a broad sense, uphold a closer imbrication between the activities of the mind and acting, stricto sensu, and consequently, foment not only the valorization of the public space, but the visibility of our acts and deeds as well, calling out the dignity of appearance in ethics.
\end{abstract}

Key-words Ethics of visibility, Hannah Arendt, Martin Heidegger, Active Perception, Appearance

* Paper delivered at Prof. Axel Honneth's Forschungskolloquium zur Sozialphilosophie in the Philosophy Department at Frankfurt University during my stay as visiting scholar in the Summer Semester/2003. An the same occasion this paper was also delivered at Kolloquium des Hannah Arendt-Zentrums, at the Carl Von Ossietzky University, Oldenburg, directed by Antonia Grunenberg. I am particularly in debt to the comments of Antonia Grunenberg, Hans Scheulen, Zoltan Szankay, Francisco Ortega, Axel Honneth, Rainer Forst and Rahel Jaeggi.

** Professora do Departamento de Direito da Universidade Estadual do Rio de Janeiro. Artigo recebido em março de 2004 e aprovado em abril de 2004. (assyb @ superig.com.br)

KRITERION, Belo Horizonte, ${ }^{\circ}$ 110, Dez/2004, p. 294-320 
RESUMO Este trabalho tem como objetivo discutir as noções arendtianas de aparência e percepção, a fim de promover um deslocamento dessas concepções do domínio geralmente associado da apreensão passiva da faculdade de conhecimento em direção a uma praxiologia da ação e da linguagem, baseada na percepção ativa. As apropriações de Arendt do "apresentar-se como" (sich hin-stellen) heideggeriano serão discutidas, bem como o "acharse no mundo" (diligere) agostiniano. Será feita a distinção de uma dupla disposição da aparência: produção e posição, que transpostas para a noção arendtiana de mundo correspondem, respectivamente, à fabricação (poiessis) do mundo, o espaço-entre objetivo do homem, e à ação (praxis) no mundo, o espaço-entre subjetivo do homem. Essas substituições conceituais, em sentido mais amplo, sustentam uma imbricação mais próxima entre as atividades da mente e a atuação, stricto sensu $e$, conseqüentemente, fomentam não só a valorização do espaço público, como também a visibilidade de nossas ações e feitos, evocando a dignidade da aparência na ética.

Palavras-chave Ética da visibilidade, Hannah Arendt, Martin Heidegger, percepção ativa, aparência

The birth and death of human beings are not simple natural occurrences, but are related to a world into which single individuals, unique, unexchangeable, and unrepeatable entities, appear and from which they depart. ${ }^{1}$

Hannah Arendt

\section{The Ontological Statute of Men - Plurality and Appearance}

"Does God ever judge us by appearances? I suspect that he does." ${ }^{2}$ With an epigraph of W.H. Auden, her friend and one of her favorite poets, Hannah Arendt announces the first chapter of The Life of the Mind, which, far from coincidently, is entitled "Appearance." Still in the first pages, Arendt asserts: "in this world which we enter, appearing from a nowhere, and from which we disappear into a nowhere, Being and Appearing coincide." ${ }^{3}$ It is my claim that The Life of the Mind, Arendt's only work actually concerning mental activities (thinking, willing, and judging), relies on visibility. It is a book coined

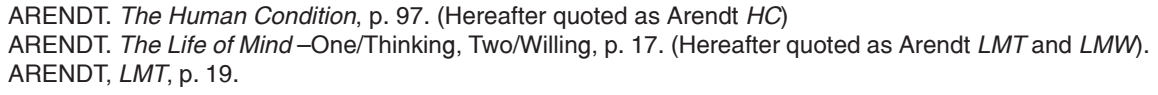


under the valorization of the appearing world. In the form of a phenomenology of action, starting 'to be' and starting 'to appear' into the world mutually correspond to one another. Arendt makes coincide, as well formulated by Taminiaux, "the dismantling of metaphysical fallacies and the manifesting of phenomena."4 This phenomenic displacement transposes features such as visibility, publicity, and communality of deeds and words into the basis of thinking, willing, and judging.

If The Human Condition was meant to be a book on the activities of vita activa looked upon through the perspective of those silent activities of reflection, i.e., a book on "thinking what we are doing;" in The Life of the Mind, Arendt challenges us to phenomenologize the vita contemplativa, ${ }^{5}$ whose privileged angle is the surface, placing thinking, willing, and judging into the domain of visibility that is crucial to an ethics of appearance based on the who. The phenomenological description of mental activities establishes the necessity to investigate those activities through the worldly categories of appearance; and, to investigate through the human condition of earth-borne creatures, and the phenomenological spatial limits of the world. ${ }^{6}$

This paper limits itself to examining the notions of appearance and perception in Arendt's aim to promote a displacement of those conceptions from the passive apprehension of the faculty of knowledge towards the domain of a praxiology of action and language. Here, Arendt's appropriations of the Heideggerian "to take one's <its> place" (sich hin-stellen), as well as, the Augustinian "finding oneself in the world" (diligere) will be discussed. ${ }^{7}$ I will distinguish two dispositions of appearance: appearance as producing a place and appearance as taking a place. Transposed into the Arendtian vocabulary on the notion of world, those features of appearance correspond respectively

4 TAMINIAUX. The Thracian Maid and the Professional Thinker - Arendt and Heidegger, p. 123

5 It is worthwhile noting that by making use of the term contemplative, Arendt by no means subsumes any notion of passivity, of inactivity (such as in the occidental metaphysical tradition), on the contrary, the author uses the term substantially linked to the idea of an activity. In The Human Condition, referring to thinking Arendt points out "although this dialogue lacks all outward manifestation and even requires a more or less complete cessation of all other activities, it constitutes in itself a highly active state. Its outward inactivity is clearly separated from the passivity, the complete stillness, in which truth is finally revealed to man." (HC, p. 291).

6 It has not been denned Arendt's paradoxical relation between belonging of the world proper to action and withdrawing from it proper to mental activities. Instead, it aims at investigating vita contemplativa under the viewpoint of vita activa. It is important to highlight that the Arendtian equalization between being and appearing neither is vied with nor put ahead with the categories of public-private, publicity-intimacy, who-what, and so on. It rather attempts to contribute to an ontological-phenomenological revitalization of appearance.

7 It is noteworthy that we are dealing with neither Heidegger's nor Augustine's philosophies properly speaking, but rather approaching their thoughts to the extent that they are seen through Arendt's lenses, to her proper way of reading them, since what is at stake here is not the exame of the relationship among them, but the meaningful Arendtian appropriations in building up her thinking. For the same reason, I will not pay attention to analyzing Arendt's fidelities on her readings. 
to fabrication, (the poiessis of the world, man's objective in-between space), and, to act and to speak, (the praxis in the world, man's subjective in-between space). Linked to the latter would be the Arendtian notion of uniqueness and specific identity, which I will attach to the idea of an active perception. The notion of aletheia as disclosed through the mode of appearance will be described. I will claim that what is at stake in Arendt's reading of Heidegger's aletheia is to confer to this "last predominance of appearance" to be in charge of the domain of truth. The outcome is to place doxa as the domain of truth that is ontologically constitutive into the plurality of disclosed appearances, i.e., aletheia in the mode of opinion. In a broad sense those conceptual replacements lead to a more imbricating relationship between the activities of the mind and acting. In a strict sense they not only foment the valorization of the public space, but also attribute mental activities with the privileged function in our acts and deeds, aiming at what I will call an ethics of personal responsibility based on appearance. ${ }^{8}$

The Arendtian ontological plurality of men's appearance resounds repeatedly throughout her oeuvre; human beings are not mere spectators of the world; and, taking the following premise as serious as possible, "we are of the world and not merely in it." This ontological dimension of "being of the world" makes coinciding being with appearing — with arriving in the world —, as well as, nonbeing with disappearing — with departing from the world, withdrawing from appearing, from presence. ${ }^{10}$ This equalization between being and appearing — even reflecting an anti-Platonism — neither reproduces the inversion of the metaphysical hierarchy, nor rejoices the post-modernisms in the manner of the flux by the sake of flux. ${ }^{11}$ It does not resound the PostNietzschean theory of changing and becoming. ${ }^{12}$ The Arendtian premise that

8 Although out of context here, the Arendtian derivations regarding appearance and perception contribute to an epistemic displacement on the modern (Kantian so to speak) notion of perception. Arendt would stand close to Bergson's and contemporarily to Merleau-Ponty's approaches on perception. My considerations concerning Arendt's notions of perception and appearance are in debt to the series of discussions about Henri Bergson that took place in the PEPAS (Research Center on Action and Subjectivity) at the State University of Rio de Janeiro, in particular to Prof. Jurandir Freire Costa.

9 (ARENDT, LMT, p. 22) To a similar account of relating appearance, ontological communality, and doxa see the second chapter "Ontologia dell'essere-in-comune" of Roberto Giusti. GIUSTI. Antropologia della Libertà - A comunità delle singolarità in Hannah Arendt, p. 99. See also: TASSIN. La question de l'apparence. In: COLLIN (Ed.). Politique et Pensée - Colloque Hannah Arendt, p 68-94.

10 See: TAMINIAUX. Le paradoxe de l'appartenance et du retrait. In: COLLIN (Ed.). Politique et Pensée Colloque Hannah Arendt, p. 95-112.

11 To quote Deleuze's post-Nietzschean approach see VILLA. Arendt and Heidegger - The Fate of the Political, p. 150. (Hereafter cited as VILLA. Arendt and Heidegger - The Fate of the Political).

12 See: VILLA. Arendt and Heidegger - The Fate of the Political, p. 150. A meaningful example is the PostNietzschean approach on Deleuze. In despite of that, I am by no means denying that Arendt as well as Heidegger would be considered in the fan of the Post-Nietzschean ontology, so to speak. 
"being and appearance coincide" surpasses rhetorical or metaphorical appeal. Reverberating Heidegger's assumption of early Greek philosophy in which being <physis> and appearing <Schein> <kryptesthai> coincide, ${ }^{13}$ Arendt ontologically re-signifies appearance, restoring its genetic matrix through the dimension of plurality of humans. To this point I agree with Villa on the influence of the twofold Heidegger discussion around the relationship between being and appearing in Introduction to Metaphysics on Arendt's vocabulary on appearance. Heidegger not only "undertakes a thorough revaluation of the ontological significance of appearance, " but also insists that even "the differential relation between being and appearance presupposes a primordial bond or unity." 14

Heidegger describes that in the beginning of Greek philosophy, "being disclosed itself to the Greeks as physis. The realm of emerging and abiding is intrinsically concomitantly a shining appearing <das scheinende Ercheinen>. The radicals phy and pha name the same thing. Phyein, self-sufficient emergence, is phainesthai, to flare up <Aufleuchten $\rangle$, to show itself, to appear." The primary nature of appearance $\langle$ Schein $\rangle$ is based on appearing $<$ Erscheinen $>$, on "self-manifestation, self-representation, standing-there, presence," 15 which turns the meaning of appearance $\langle$ Schein $\rangle$ into the same as being. ${ }^{16}$

13 At this matter I am of the same opinion as Villa's, i.e., Arendt ontological and epistemological foundation of making being and appearing coincide assembles directly to chapter four of Heidegger's An Introduction to Metaphysics. In The Life of the Mind, Arendt not only takes the Heideggerian considerations as her starting point to discourse appearance, but she even literally quotes Heidegger's dictions regarding the three disposing types of Schein in chapter four of An Introduction to Metaphysics, p. 98 (Einführung in die Metaphysik, p. 71) This task comprises a seminar taught by Heidegger in Freiburg 1935. It is noteworthy to highlight that the Heideggerian influence on Arendt's notion of appearance is not limited to those distinctions regarding Schein in An Introduction to Metaphysics. Other Heidegger's conceptions, to quote only the notion of Erschlossenheit in Being and Time, also add contributions to Arendt's notion of appearance. See: Sein und Zeit, 1993, 17th ed. (Hereafter quoted as Heidegger, An Introduction to Metaphysics, followed by the original page).

14 VILLA. Arendt and Heidegger - The Fate of the Political, p. 152. Arendt's understanding of appearance is more in conformity with the phenomenological vocabulary as a path to avoid the metaphysical fallacies. This latter lays down on the assumption that Being stands versus Appearance, figuring out at the bottom of all two-world theories. "That traditional hierarchy arises not from our ordinary experiences with the world of appearances, but rather, from the not-at-all ordinary experience of the thinking ego." (ARENDT, LMT, p. 42) In a certain sense, Arendt is right in pointing out that the fallacious two-worlds theory came from a genuine experience of the thinking ego throughout the Western philosophical tradition. Nonetheless, through Arendt's own notion of thinking as an activity necessarily worldly conditioned, it is possible to unveil the appearing power of the thinking activity and at the same time to dismantle the two-world theories.

15 HEIDEGGER. An introduction to metaphysics, p. 101 (Original EM, p. 76-77).

16 In An Introduction to Metaphysics, Heidegger classifies three modes of Schein. "On closer scrutiny we find three modes of Schein: 1) Schein as radiance and glow; 2) Schein and Scheinen as appearing, as coming to light; 3) Schein as mere appearance or semblance <Anschein>. But at the same time it becomes clear that the second variety of 'Scheinen,' appearing in the sense of showing itself, pertains both to Schein as radiance and to Schein as semblance, and not as a fortuitous attribute but as the ground of their possibility." [Genauer besehen finden wir drei Weisen des Scheines: 1. den Schein als Glanz und Leuchten; 2. den 
The similitude with the Heideggerian terms stand neither aleatory not imitative. What is noteworthy of Heidegger's resemblance here is to maintain that Arendt, in a political ontology of appearance,$^{17}$ retraces Heideggerian terminology to justify the continuity between the experience of 'being' as a self-emerging appearance, and the Greek political realm as a space of appearance. ${ }^{18}$ Based on Heidegger's 1935 lecture, Arendt would literally juxtapose the phenomenic genesis of appearance and the ontological genesis of being, locating worldly otherness into the heart of the human genesis. In Freiburg, Heidegger describes that "for the Greeks standing-in-itself $<$ Insichstehen > was nothing other than standing-there, standing-in-the-light $<$ Da-stehen, Im-Licht-stehen $>$. Being means appearing. Appearing is not something subsequent that sometimes happens to being. Appearing is the very essence of being < Sein west als Erscheinen>."19

Thus, appearance veiled as emerging self-manifestation can equally be described as being. And in following the sequence of Heidegger's etymological hermeneutics of the early Greek vocabulary, being, - as what comes to light, what appears on the scenario - implies also "to take one's <its> place < sich hin-stellen $>$, to produce <her-stellen $>$ something." ${ }^{20}$ Such production of a world would assume a more affirmative sight in Arendt. I will distinguish two different dispositions of appearance in Arendt: appearance as producing a place, and appearance as taking a place. Man is assured of his appearance in the world through a twofold operation: not only by means of fabricating a world, of producing a world. Humans gain affirmation through poiessis of the world and the so called world of artifact; but also by means of one's own space of action, of moving, of taking a place, of praxis; taking into account that praxis has as its sine qua non condition in the very manufactured world.

Although Arendt is indebt to Heideggerian terminology, the author of The Human condition would attribute an intrinsically positive status to plurality,

\footnotetext{
Schein und das Scheinen als Erscheinen, den Vor-schein, zu etwas kommt; 3. den Schein als bloßen Schein, den Anschein, den etwas macht. Zugleich wird aber deutlich: das an zweiter Stelle genannte $>$ Scheinen<, das Erscheinnen im Sinne des Sichzeigens, eignet sowohl dem Schein als Glanz, wie auch dem Schein als Anschein und zwar nicht als eine beliebige Eigenschaft, sondern als Grund ihrer Möglichkeit.]" HEIDEGGER, An Introduction to Metaphysics, p. 100 (Original EM, p. 76).

17 Cf. VILLA. Arendt and Heidegger - The Fate of the Political, p. 152. I borrowed this expression from Villa, who, instead, named Heidegger.

$18 \mathrm{Ibidem}$, p. 153. Nonetheless, contrary to Arendt, Heidegger establishes a suspicious relation towards appearance, such as the concealment of the truth (aletheia) of Sein. See: BERNSTEIN. Provocation and Appropriation: Hannah Arendt's Response to Martin Heidegger. Constellations, v. 4, n. 2, p. 153-171; FISTETTI. Hannah Arendt e Martin Heidegger - Alle origini della filosofia occidentale; BAKAN. Arendt and Heidegger: the episodic Intertwining of Life and Work. Philosophy \& Social Criticism, v. 12, n. 1, p. 71-98. 19 HEIDEGGER, IM, p. 101 (Original EM, p. 77).

20 Ibidem, p. 102 (Original EM, p. 78).
} 
appearance and visibility by transfiguring Heidegger's notion of authenticity. For Arendt, the world does not embody the possibility of hiding prospect for authentic solitude, to put in Heidegger's terms. On the contrary, the plural world is the very space of human genesis, engendered under their worldly condition. Plurality described as the ontological statute of human beings is often reverberated throughout Arendt's works. "She has disclosed the deep structure of human action as interaction." ${ }^{21}$ Arendt takes Heidegger's terminology to increase what Heidegger precisely devaluates. As well formulated by Benhabib "the space of appearance is ontologically revaluated by her, precisely because human beings can act and speak only with others, and insofar as they appear to others." 22

As early as The Concept of Love in Augustine, ${ }^{23}$ without neglecting Augustine's indebtedness to Greek philosophy, Arendt highlights Augustine's two conceptions of the World (mundus). In distinction to God's creation of heaven and earth (Fabrica Dei), stands the human world (saeculum), formed by dwelling-place and love (diligere). The human world - constituted under the aegis of the former pre-existing created God's world, in a secular vocabulary, the physical world of nature - , expresses the world made by men. Nevertheless, to produce a world does not portray man's belonging to the world, to describe man's being of the world (de mundo). ${ }^{24}$ It is necessary to become part of the world, to find oneself in it and be able to turn the world "into the self-evident home of man." One must be able to place oneself in the world. ${ }^{25}$

Appearance and disappearance of the world resound within the ontological condition of plurality of men through Augustine's conception of natality by synonymizing the terminologies "to live" and "to be among men" (inter hominess esse), as well as, "to die" and "to cease to be among men" (inter hominess esse desinere). ${ }^{26}$ Through coinciding natality and the beginning of worldly appearance with being, and death with the end of worldly appearance,

21 BENHABIB. The Reluctant Modernism of Hannah Arendt, p. 111.

22 Idem.

23 Even Arendt's considerations on Augustine's conception of world are already under the influence of Heidegger's distinctions of world in Augustine's thought mentioned in Vom Wesen Des Grundes, (E. Husserl - Festschrift, Halle, 1929). Arendt quotes as Heidegger's account a reference in her thesis on the concept of love in Augustine. See: ARENDT. Love and Saint Augustine, p. 66, note, 80. (Der Liebesbegriff bei Augustin. Berlin: J. Springer, 1929 Hannah Arendt's Papers, The Manuscript Division, Library of Congress, 033082, container 72. Also "Love and Saint Augustine - An Essay in Philosophical Interpretation." 033237, container 73. From Hannah Arendt Archive, Hannah Arendt Forschungszentrum, Carl von Ossietzky, Universität Oldenburg). (Hereafter cited as $L S A$ ) See: SAVARINO. 'Quaestio mihi factus sum' - una lettura heideggeriana dil il concetto d'amore in Agostino, p. 249-269.

24 See ARENDT, LSA, p. 66.

25 Idem.

26 ARENDT, $H C$, p. 8. 
the time in-between birth and death (life) is composed "in the mode of relation." ${ }^{27}$ This time-space interval between "not yet" and "no more" "have appearance as such in common, first, an appearing world and second, the fact that they themselves are appearing and disappearing creatures, that there always was a world before their arrival and there always will be a world after their departure." ${ }^{28}$ Distinctly from the reality of life, whose dependence comes from "the intensity in which life is felt." 29 The permanency and durability of what is created assure the reality of the world. Even in regard to the reality of life, one still presupposes the eternal recurrence of natality. On the other hand, the birth of man also supposes durability and stability in the world. Such a continuously steady and objective man-fabricated world provides an objective space of reality (objective in-between), precisely the world of objects, and also, a subjective space of reality (subjective in-between) which is the common otherness of language and action. In its broadest sense the spectators exist as a sort of factual tutor of reality. "That appearance always demands spectators and this implies that an at least potential recognition and acknowledgment has far-reaching consequences for what we, appearing beings in a world of appearances, understand by reality, our own as well as that of the world." ${ }^{31}$

\section{Active Perception placing Uniqueness}

In The Human Condition's considerations on the Public, two contributions to the notion of appearance can be denoted. Both engender the above phenomenological and epistemic constitute of otherness. First, appearance as being in the presence of others, - being heard and seen by them - is what guarantees reality. The plurality of men is more essential in constituting the feeling of reality than the evident and stable differentiation of the objects. ${ }^{32}$ It is this "bright light of the constant presence of others on the public scene," 33

\footnotetext{
27 ARENDT, LSA, p. 53.

28 (ARENDT, LMT, p. 20) Also in The Human Condition Arendt underscores "Birth and death presuppose a world which is not in constant movement, but whose durability and relative permanence makes appearance and disappearance possible, which existed before any one individual appeared into it and will survive his eventual departure." (HC, p. 97)

29 ARENDT, $H C$, p. 120

30 See ARENDT, HC, p. 183.

31 (ARENDT, LMT, p. 46) It is noteworthy to underline that spectators place a crucial role in the guaranteeing of this in-between subjective reality, and they also propitiate the possibility to judge, which is the outcome of a common world.

32 Parekh highlights that in Arendt, "for our sense of reality, the plurality of perceiving agents is even more important than the plurality of objects." PAREKH. Hannah Arendt and The Search for a New Political, p. 86. 33 ARENDT, HC, p. 51.
} 
that constitutes reality. Men are "fit for worldly existence," in that they are of the world, "precisely because they are subjects and objects - perceiving and being perceived - at the same time." ${ }^{34}$ These inter-actions, between human beings' perceiving and being perceived, ground us in the reality of the world. "Not my own feelings, nor even material objects, but only the corroboration by other independent centers of consciousness can establish beyond doubt the reality of my experience." 35 Our sense of reality is deeply rooted in the fact that we belong to a plural world of appearances, seeing and being seen by others.

Secondly, the term public can be defined as the world itself. ${ }^{36}$ The world as artifact is built by us, and at the same time, works as the place in which our existence is guaranteed. Only in plurality can man build a world that creates the ontological condition of his existence. This ontological circumstance is based by no means on the metaphysical unchangeable universal order, but instead, "distinguished from our privately owned place in it," 37 through visibility, publicity, permanence and movement in the world. Each public space, - each Lebensform, each community, with its cultural, and political specificity guarantees and establishes the structured conditions of their members, of their world. Men's dwelling-place gathers a dual togetherness.

On the one hand, it is a world fabricated by human hands, a man-made world which, consequently, does not coincide with the physical world, the earth, nature or organic cycles. On the other hand, the world as a public place takes on significance. Those man-made objects are spatially located, taking upon themselves the role of separating and relating the human beings, a world that is able to stand in-between them. The sameness of the objects fabricated by men, that is to say the world in stricto sensu, guarantees the common world but also allows possibility for distinct perspectives and different perceptions. "Under the conditions of a common world, reality is not guaranteed primarily by the 'common nature' of all men, but rather by the fact that, differences of position and the resulting variety of perspectives notwithstanding, everybody is always concerned with the same object." 38 The spatiality of man-made worldly objects guarantees the durability and a relative permanence of the world beyond the individual appearances and disappearances. This attribute of spatiality in the manufactured world creates a sort of manoeuvre's space, an

34 ARENDT, LMT, p. 20.

35 PAREKH. Hannah Arendt and The Search for a New Political, p. 87.

36 Cf. ARENDT, HC, p. 52.

37 (ARENDT, HC, p. 52) See: TASSIN. Virtuosité de l'action, vérité de l'apparence. In: TASSIN. Le Trésor Perdu - Hannah Arendt, L'Intelligence de L'Action Politique, p. 275.

38 Ibidem, p. 58. 
in-between shared space in which each human being configures his perception, his unique and distinctive sight of the world. It is in such terms that we can trace similarities with Bergson's notion of perception, in which "the perception disposes of the space." 39 It can be assumed that each unique perspective is constituted by already taking into account the plurality of men's perceptions, which leads to a complete avoidance of taking perception as "normatively neutral as the concept of individuating cognition." 40 Perception is thus pregiven in solitude and as a passive cognizable apprehension. In other words, perception would be, still in Bergson's slightly altered terminology, "our possible influence upon the objects," 41 bringing perception to a much closer connection to action instead of to knowledge and for that very reason, limiting it to the manoeuvre's space built by men. ${ }^{42}$

Arendt belongs to a generation in which a sort of revival of the hierarchy of appearance through phenomenology and existentialism took place, particularly with Heidegger, Merleau-Ponty, and Alexandre Kojève. ${ }^{43}$ It is quite meaningful that Arendt quotes Merleau-Ponty, who under Heidegger's early Greek terminology, describes appearance as an ontological changeable achievement, impregnated by the value of experience in its outside manifestation. "For when an illusion dissipates, when an appearance suddenly breaks up, it is always for the profit of a new appearance which takes up again for its own account the ontological function of the first. The dis-illusion is the loss of one evidence only because it is the acquisition of another evidence ...there is no Schein without an Erscheinung, every Schein is the counterpart of an Ercheinung." 44 In that being and appearing coincide, what 'I am' is the way I emerge <physis> into the public space of appearance, in which every $<$ Schein $>$ implicates in a <Erscheinung $>$. The fundamental ontological turn attributing to publicity and visibility in the way we dispose ourselves in the public space, deprives the genesis of human being's ontology from any kind

39 [la perception dispose de l'espace dans l'exacte proportion où l'action dispose du temps.] BERGSON. Matière et Mémoire, p. 183.

40 HONNETH. Invisibility: On the Epistemology of "Recognition," "Unsichtbarkeit - Über die Moralische Epistemologie von >Anerkennung<", p. 26. I am in dept to prof. Axel Honneth's discussion on visibility.

41 See: BERGSON. Matière et Mémoire, p. 187.

42 What seems crucial, and Arendt's notion of perception in my view leads to a similar direction, is to pay attention, as Bergson highlights, not to how perception is originated, which would suppose a whole image, but rather, to how perception is framed, which infers, de facto, to what interests each of us. ["Ce que vous avez donc à expliquer, ce n'est pas comment la perception naît, mais comment elle se limite, puisqu'elle serait, en droit, l'image du tout, et qu'elle se réduit, en fait, à ce qui vous intéresse."] Ibidem, p. 190.

43 Hannah Arendt suffered influence from the renowned seminar taught by Alexandre Kojève on Hegel's The Phenomenology of the Mind in École des Hautes Études, called "Introduction to the reading of Hegel," which during the 1933-1939 period, dictated the interpretation of Hegel's phenomenology in France, exerting influence upon a series of thinkers, Arendt, among them.

44 ARENDT, LMT, p. 26. Quoted from Maurice Merleau-Ponty, The Visible and the Invisible, p. 170. 
of praedetermino. I claim that Arendt's account of appearance is grounded in a producing [Erscheinung] perception that takes place by acting in the common realm of appearance. Contrary to most $17^{\text {th }}$ and $18^{\text {th }}$ centuries epistemology, through Arendt's account of appearance, the space of visibility - shaped already by fellows who act and speak together - , creates the potential for such, if we can call it, an active perception, or using Honneth terminology, "an evaluative perception." ${ }^{45}$ This Erscheinung, this production of an appearance is built in Arendt under the form of it-appears-to-me. The world displays a "twofold law of appearing to a plurality of sensitive creatures each equipped with the faculties of perception. Nothing that appears manifests itself to a single viewer capable of perceiving it under all its inherent aspects. The world of appears in the mode of it-appears-to-me, depending on particular perspectives determined by location in the world as well as by particular organs of perception." 46

This active perception in the shape of it-appears-to-me introduces another crucial dimension of Arendt's geneses of appearance: the notion of uniqueness and specific identity. The Greek vocabulary of an ontological spatial simultaneity between being and appearance, on the one hand, and the producing of an appearance, on the other hand, are meaningful not only to justify the link between 'being' as physical appearance and the Greek political domain as a place of appearance. ${ }^{47}$ This is reverberated through Arendt's Heideggerian accounts. It also concerns the ontological-existential foundation of human uniqueness, a phenomenological foundation that is only possible among men (inter se). Arendt ascribes the uniqueness of each person to the sphere of the plural and apparent world, and privileging natality, the par excellence domain of affirming life among men, upon death, inexorable withdrawal from the world. "In acting and speaking, men show who they are, reveal actively their unique personal identities and this make their appearance in the human world, while their physical identities appear without any activity of their own on the unique shape of the body and sound of the voice. This disclosure of 'who' in

45 See: HONNETH. Invisibility: On the Epistemology of "Recognition," "Unsichtbarkeit — Über die Moralische Epistemologie von >Anerkennung<", p. 27.

46 ARENDT, LMT, p. 38.

47 As Villa points out, and I agree with him, Heidegger comes here to justifying 'the continuity between the experience of physis as self-emergent appearance and the Greek understanding of the political realm as a space of appearance." VILLA. Arendt and Heidegger - The Fate of the Political, p. 153. Nonetheless, as it is well known, contrary to Arendt, Heidegger establishes a suspicious relationship towards appearance, such as the concealment of the Sein's truth (aletheia) in Mitsein, as the space of fallenness (Verfallenheit), and of inauthenticity (Uneigentlichkeit). See ØVERENGET. Heidegger and Arendt: Against the Imperialism of Privacy. Philosophy Today, v. 39, n. 4/4, p. 430-444; GROSSMANN. "Im Anfang liegt alles beschlossen": Hannah Arendts politisches Denken im Schatten eines Heideggerschen problems, p. 35-47. 
contradiction to 'what' somebody is - his qualities, gifts, talents, and shortcomings, which he may display or hide — is implicit in everything somebody says and does." 48

Arendt's notion of uniqueness takes its place in the visibility of one's deeds and speech through the public space of appearance; through it-appearsto-me as a way of shaping perception and appearance whose sine qua non condition is the social interaction with others. Perception can be equalized to its etymologic meaning by presupposing the attention required to act upon objects, the attention demanded from "reflection; thus, the external projection of an image actively created, identical or similar to the object which comes to frame its borders." 49 Even though Arendt by no means refuses the existence of man's inner life, she sustains that human uniqueness is disclosed only by who we are through words and acts in the realm of appearance. Our identity is not comprised in the solipsism's mode. It is evident to Arendt that who we are is constituted in the public space of appearance, using Heidegger's terminology against Heidegger, being's authenticity takes place in the course of our speech and deeds in the appearing world through an active (evaluative) perception. We exist as we appear. Uniqueness takes place by making oneself visible into the public space, and to a certain extent through choosing how we want to appear. ${ }^{50}$ We hold the power to either approximate or alienate ourselves from/ to the others and the world by means of our affirmations and negations, namely, by how we make our appearance into the world; or through "the form of a process of reciprocal regulation of affect and attention," 51 in the interrelated space of appearance. Uniqueness also resounds the Augustinian notion of world as the dwelling-place and love (diligere), since to be of the world implies the necessity to fit oneself into it and to turn the world "into the self-evident home of man." This fitting oneself into the world takes the form of specific identity. In this sense, "the world is dilectores mundi. Or the love of the world constitutes the world for me, fits me into it. Hence: From my affirmation or negation will depend to whom and to what I belong." 52 The notion of uniqueness reaches

48 (ARENDT, HC, p. 179) By ontologically raising the status of appearance one by no means intends to equalize interiority and appearance (the very basis of distinction between the private and the public domains), but rather, to privilege the Arendtian who we are upon what we are (gifts, qualities, talents, and so on).

49 (Emphasis added) BERGSON. Matière et Mémoire, p. 188.

50 The traditional terminologies of authenticity regarding ethics hold mainly the notions of universal conception of truth as well as a notion of truly inner man. By displacing the notion of truth to Aletheia, namely, to opinion, to the notion of the it-seems-to-me, dokei moi, I would say that Arendt replaces authenticity in a deferent dimension, namely, to uniqueness, to distinctness in publicity.

51 HONNETH. Invisibility: On the Epistemology of "Recognition," "Unsichtbarkeit — Über die Moralische Epistemologie von >Anerkennung,<" p. 17.

52 ARENDT. Basic Moral Propositions, p. 024560. Unpublished manuscript from 1966. ARENDT. Basic Moral Propositions. Lectures 1966. 
Arendt's dimension Amor Mundi, through who we are and how we act in the domain of appearance, in the public space, how we choose to make ourselves visible in the world.

Composing an allusion of the world as an acting stage, Arendt draws the notion of it-appears-to-me, as that "which answers the fact of one's own appearance, living things make their appearance like actors on a stage set for them. The stage is common to all who are alive, but appears different to each species and specimen. Seeming — the it-appears-to-me, dokei moi — is the mode in which an appearing world is acknowledged and perceived. To appear always means 'to seem' to others, and this seeming varies according to the standpoint and the perspective of the other. Every appearing thing acquires, by virtue of its appearingness, a kind of disguise that may indeed — but does not have to hide or disfigure it. Seeming corresponds to the fact that every appearance, its identity notwithstanding, is perceived by a plurality of spectators". ${ }^{53}$

This mode of it-appears-to-me shapes the uniqueness of each of us through an active perception, disposed by the manner in which we appear and built under a relational form. Notwithstanding the fact it seems tautological, it actually conceals two stages. On the one hand, we produce the appearing artifact world. On the other hand, this world holds the condition of possibility for our active and unique perceptions. ${ }^{54}$

The appearing world is necessary to locate each it-appears-to-me. Contrary to the classical adequation rei et intellectus, as pure knowledge, in which perception is merely reduced to a passive "thought of perceiving," 55 an epistemological turn can here be ascribed. Through an Arendtian account, it is possible to recognize two distinct kinds of affectedness in perception, namely, as being affected and as affecting the world. Firstly, much closer to its modern understanding, in its passive account of being affected by the world, perception is itself the very presence of this between-space of the human- built world of artifact that makes the world durable, this "chief worldly property of 'standing still and remaining."

53 (ARENDT, LMT, p. 21).

54 It is noteworthy to highlight that common sense has a double attribute, which guarantees by the one hand the common perception, and by the other hand, propitiates the active perception especially through the itseems-to-me as opinion, derived from the faculty of judgment, through imagination. Active perception in terms of the faculty of judging appears as the power of imagination.

55 Arendt highlights that "What Merleau-Ponty has to say against Descartes is brilliantly right: 'To reduce perception to the thought of perceiving... is to take out an insurance against doubt whose premiums are more onerous than the loss for which it is to indemnify us: for it is to ... move to a type of certitude that will never restore to us the 'there is' of the world."' (MERLEAU-PONTY, The Visible and the Invisible, p. 36-37, apud ARENDT, LMT, p. 48-49)

56 ARENDT, LMT, p. 40. 
Secondly, perception consists in the manner we apprehend the world through our uniqueness; not only by appearing as such, as Shein, but also, and consequently, by choosing and producing [Erscheinung] how we appear in it, how we fit into it, as it-appears-to-me. We must take into consideration that those accounts on it-appears-to-me, - subsequently gathered by Arendt to the notions of opinion and judgment - , are in a shared world. "All that existentially concerns you while living in the world of appearances is the 'impressions' by which you are affected. Whether what affects you exists or is mere illusion depends on your decision whether or not you will recognize it as real. ${ }^{, 57}$ What Arendt (making use of Epictetus) calls impressions, implies a turning from a passive mold of perceiving, i.e., from a seen object, to an active choice concentrating on the act to see instead, which leads perception to be linked to the capacity of imagination and memory tied to experiencing the world.

\section{Self-presentation versus Self-display}

This producing attribute of appearance bears more worthy distinction in approaching an ethics based on appearance in Arendt. It refers to a differentiation drawn between self-display and self-presentation. Self-display stands for a sort of deflated notion of Shein, a mere "urgency to appear," with whatever properties any lively creature carries. It demands simple consciousness that both humans and animals possess. The notion of self-display is meaningful only to reinforce that appearance is not an inner self. According to Arendt, even the German Selbstdarstellung is misleading, since one by no means displays or shows a "self," but rather a person or a creature. ${ }^{58}$ Whereas selfpresentation embraces in the first place an active and conscious choice of the image shown by means of how men present themselves through speech and acts, "what in their opinion is fit to be seen and what is not. This element of deliberate choice in what to show and what to hide seems specifically human. Up to a point we can choose how to appear to others, and this appearance is by no means the outward manifestation of an inner disposition." 59 The capacity to choose what to hide and what to show leads the notion of uniqueness out of the domain of natural talents, gifts, abilities, i.e., out the realm of "what" we are, to use Arendt's own terminology. It rather attributes uniqueness with the 
responsibility to choose what is fitted to the visibility of the public world, to a world in which I am never alone; a man-made world intrinsically concerned with collective interests. I am tempted to say that our specific identity, instead of carrying just private qualities that concern only the self, rather deeply relate with community. In terms of Arendt's political theory, self-presentation stands towards the human ability to be free. ${ }^{60}$

It is remarkable how Arendt through the notion of self-presentation displaces appearance to be identified with the merely outward correspondent of the inner "natural" inclination. Appearance would assume a choosing presentation in the world, a producing appearance, intrinsically constituted in the relational form.

Instead of an inner condition of the true self, the criteria for "success and failure in the enterprise of self-presentation depend on the consistency and duration of the image thereby presented to the world." 61 Here we have a theoretical movement on the notion of durability, placing not only the condition reality of the in-between man-made world, but also, influencing the proper condition of aletheia, of opinion. The power of opinion relies on the capacity of maintaining a consistent and durable image into the plural world, a reliable appearance in the world. In fact, appearance in the form of it-appears-to-me (doxa) carries the latent possibility of dismissing. This is possible not only through pretending in the case of the actor, but also by mistaking or illusion in the case of the spectator. ${ }^{62}$

By highlighting appearance, it has not been subsumed that the appearing world mirrors only an external correspondence of an inner truth which is a mere viewpoint modification from an inward reflection towards the outward reflection. Leading aletheia to the field of visibility, one has to deal with dissimulation and illusion whose consequence relies on the necessity to built a conception of truth as it-appears-to-me based fundamentally on visibility, durability and consistence. Only in self-presentation is it possible to verify truth and reality, since against pretense and dissimulation stand consistence. ${ }^{63}$

60 See: CURTIS. Aesthetic Foundations of Democratic Politics in the Work of Hannah Arendt, p. 20.

61 ARENDT, LMT, p. 36.

62 Cf. ARENDT, LMT 36. To be able to hold a consistent image embraces important features of an ethics based on appearance.

63 ARENDT: "Only self-presentation is open to hypocrisy and pretense, properly speaking, and the only way to tell pretense and make-believe from reality and truth is the former's failure to endure and remain consistent." (ARENDT, LMT, p. 36) Hypocrisy stands for a good illustration of how the failure of consistence and durability of words and deeds means the breaking of a promise with the world. "It has been said that hypocrisy is the compliment vice pays to virtue, but this is not quite true. All virtue begins with a compliment paid to it, by which I express my being pleased with it. The compliment implies a promise to the world, to those to whom I appear, to act in accordance with my pleasure, and it is the breaking of the implied promise that characterizes the hypocrite. In other words, the hypocrite is not a villain who is pleased with vice and hides his pleasure from his surroundings." Ibidem, p. 36. 
By juxtaposing opinion as a domain of rational truth, it still remains distinct from rational truth and what Arendt named 'factual truth'. This latter is described as the evident truth of facts and events, which despite of being self-evident, also depends on opinion. The events and happenings require dialogue, discussion and persuasion to come to the fore; thus, relying on opinion.

Actions sustain unpredictable outcomes, the well-known agonistic dimension of acting. Nevertheless, in terms of ethics, durability and consistence of presenting ourselves, our specific identity and image, play a fundamental role. Durability and consistence are tools towards an ethical approach that holds not only vita activa, but vita contemplativa as well.

Thus, I will add on this topic of self-presentation another implication of choosing appearance, leading to its link with the faculties of the mind. Selfpresentation entails a "capacity inherent in the reflexive character of mental activities." "When I make such a decision, I am not merely reacting to whatever qualities may be given me; I am making an act of deliberate choice among the various potentialities of conduct with which the world has presented me." ${ }^{55}$ This act of choice and presentation is relevant to our appearance and implies a quality of reflection peculiar to the mental activities as described by Arendt. ${ }^{66}$ The step on the path towards the visibility of mental life occurs by dislodging the notion of truth from the rational achievement of our logical capacities, from any substantial concept of truth, toward the Greek conception of truth as aletheia, - as the world discloses to each of us - , which Arendt would link to the notion of doxa, opinion. Self-presentation is accountable for how we wish to appear.

\section{Aletheia Disclosed through Appearance and the Status of Doxa}

In a Marburg lecture course taught by Heidegger in 1924-25, at the same period that he was elaborating his magnum opus, Sein und Zeit, Arendt, among other well-known philosophers, absorbs first signs of a non-essentialist conception of truth. ${ }^{67}$ Through an Aristotelian reading of Plato, Heidegger

\footnotetext{
64 Ibidem, p. 29.

65 (Ibidem, p. 37) It is noteworthy that the use of the word "choice" by no means embraces any heritage of the Contemporary American political theory account of the so-called fashioned "rational choice." This latter would rather sustain what Arendt foremost calls attention for, that is, ends-means activities, such as homo faber's activities. It has no reference either to the notion of pure cognition, which, akin to fabrication, with its instruments and tools, is a process leading to a proposition, with a beginning and end, and whose utility can be demonstrated. I am grateful to prof. Antonia Grunenberg on this accuracy of terminology.

66 (ARENDT, LMT, p. 37) There is an "undeniable relevance of these self-chosen properties to our appearance and role on the world." Idem.

67 Taminiaux captures precisely this Heideggerian heritage in Arendt. "It is well known that as soon as Arendt
} 
opens The Sophist expressing the ancient meaning of truth. For the Greeks truth refers to a negative, in the sense that $\alpha^{\prime} \lambda \eta^{\prime} \theta \varepsilon 1 \alpha$ (aletheia), the Grecian equivalent word for truth, holds a $\alpha$-privative. “A $A \eta^{\prime} \theta \varepsilon 1 \alpha$ means: to be hidden no longer, to be uncovered <nicht mehr verborgen sein, aufgedeckt sein>,"68 that which is disclosed. This disclosure transposed to the domain of appearance comes up as its own mode of appearance, leading truth to be related with different modes of appearance, since being and appearance coincide. ${ }^{69}$ "Appearing is the power that emerges. Appearing makes manifest. Already we know then that being, appearing, cause to emerge from concealment $<$ Verborgenheit $>$. Since the being <Seiendes $>$ as such $i$ s, it places itself in and stands in unconcealment <Unverborgenheit>, aletheia. We translate, and at the same time thoughtlessly misinterpret, this word 'truth'. [...] The power that manifests itself stands in unconcealment. In showing itself, the unconcealed as such comes to stand. Truth as un-concealment is not an appendage to being." 70

One must take into account that the Heideggerian project of a fundamental ontology (at the bias of Plato) turns the Aristotelian Praxis into an ontological motion of solipsism and denies authenticity to the plural realm of doxa and lexis, the very reason why The Sophist gave rise in Arendt to "a set of problems of immediate and urgent importance."71 I think that by making use of Heidegger's reading of Greek nomenclature, Arendt links the notion of truth directly with appearance at the expense of dismantling the well-known dichotomy between true being and mere appearance, the so called two-worldtheory. Aletheia, meaning in Greek "that what is disclosed <nicht mehr verborgen sein>," takes place through appearance, displacing truth from the domain of noumena to the realm of phenomena which is the domain of visibility. This reverberates the main themes of The Human Condition: work, action, fame, immortality, public and private domains. "This truth - a-letheia, that

attempted those demonstrations of in The Human Condition she reappropriated in her own way the legacy of the Greek tradition. Regarding this point, many experts of political theory were surprised by the stress she was putting on Homer or Pericles and by her argument for doxa, or by her insistence on themes such as immortality and eudaimonia. All this is less surprising if one keeps in mind that, most of the time, these analyses are retorts to the reappropriation of the Greeks conducted by Heidegger at the time of the genesis of his fundamental ontology and already, more specifically, in the lecture course on The Sophist." TAMINIAUX. The Thracian Maid and the Professional Thinker - Arendt and Heidegger, p. 12.

68 HEIDEGGER. Plato's Sophist, p. 11. Published in German as Platon: Sophistes, p. 16.

69 Heidegger writes: "Disclosure, however, in relation to which there is a $\alpha^{\prime} \lambda \eta^{\prime} \theta \varepsilon 1 \alpha$, is itself a mode of Being. [...] Insofar as disclosure and knowledge have for the Greeks the goal of $\alpha^{\prime} \lambda \eta^{\prime} \theta \varepsilon 1 \alpha$, the Greeks designate them as $\alpha^{\prime} \lambda \eta^{\prime} \theta \varepsilon v^{\prime} \varepsilon ı$, i.e., designate them in terms of what is achieved in them, $\alpha^{\prime} \lambda \eta^{\prime} \theta \varepsilon 1 \alpha$." (HEIDEGGER, Plato's Sophist, p. 12. (Original, p. 17).

70 HEIDEGGER, An Introduction to Metaphysics, p. 102. (Original, p. 77-78).

71 TAMINIAUX. The Thracian Maid and the Professional Thinker - Arendt and Heidegger, p. 9. 
which is disclosed (Heidegger) - can be conceived only as another 'appearance,' another phenomenon originally hidden but a supposedly higher order, thus signifying the lasting predominance of appearance."72 At this point, what is at stake in Arendt's reading of Heidegger's Aletheia is that by conferring to this "last predominance of appearance" to be in charge of the worth domain of truth, aletheia can be described in terms of opinion.

Heidegger bonds aletheia with speaking as its more direct mode; “ $\alpha \prime \lambda \eta^{\prime} \theta \varepsilon v^{\prime} \varepsilon \mathrm{Iv}\left[\right.$ Aletheia] shows itself most immediately in $\lambda \varepsilon^{\prime} \gamma \varepsilon \mathrm{v}$ [Sprechen, to speak]," which together with acting, constitutes the main Arendtian domains of being of the world. "This $\lambda \varepsilon^{\prime} \gamma \varepsilon \mathrm{v}$ was for the Greeks so preponderant and such an everyday affair that they acquired their definition of man in relation to this phenomenon and thereby determined man as $\zeta \omega^{\prime}$ ov $\lambda o^{\prime}$ yov $\varepsilon^{\prime} \chi 0 v$ [a mode of Being of man]." "ᄁ3 This was in the sense of being shaped by speech and language. This relational mode of being, - since creatures as phenomena, namely, as "beings as they show themselves in the various possibilities of their becoming disclosed," - necessarily requires " $\lambda \varepsilon^{\prime} \gamma \varepsilon t v$ : to speak about." ${ }^{\prime 74}$ Retorting Heidegger's excellence of bios theōrētikos rejoiced through Plato's struggle against doxa, Arendt reverberates doxa as the celebration of Aletheia, displacing the realm of truth from noumenic singularity to phenomenic plurality. "The shift from rational truth to opinion implies a shift from man in the singular to men in the plural, and this means a shift from a domain where, Madison says, nothing counts except the 'solid reasoning' of one mind to a realm where 'strength of opinion' is determined by the individual's reliance upon 'the number which he supposes to have entertained the same 'opinions' - a number, incidentally, that is not necessarily limited to one's contemporaries." 75 In other words, doxa places the ontological significance of plurality into the domain of disclosed appearances. ${ }^{76}$

Arendt turns speech (lexis) and acting (praxis), both coming from the

72 ARENDT, LMT, p. 24.

73 HEIDEGGER. Plato's Sophist, p. 12 (Original, p. 17.) "ËÝãåéí ["to speak"] is what most basically constitutes human Dasein. In speaking, Dasein expresses itself — by speaking about something, about the world." (Idem.)

74 HEIDEGGER. Plato's Sophist, p. 6. (Original, p. 11) A crucial distinction, as Heidegger points out, is that through Husserl's Logical Investigations, phenomena was linked to specific types of lived experience, judgment, and acts of knowledge.

75 ARENDT. Truth and Politics, p. 235. (Hereafter cited as TP)

76 Such a feature is well formulated by Villa: "Here we see the gap that separates Heidegger's dialectic of concealment and revealment from Arendt's appropriation. Heidegger's equation of disclosure or unconcealment with truth (aletheia) leads him to identify the illuminative activity of the Greeks not with doxastic political action, but rather with the poetic or creative activity that 'wrests' the truth of Being concealed by the 'dimmed down' appearances of the public realm." VILLA. Arendt and Heidegger - The Fate of the Political, p. 154. 
domain of visibility, into the categories through which man is disclosed. One of the most meaningful basic concepts of Greek philosophy which - deeply reappropriated by Arendt and remote from Heidegger's fundamental ontology - would place a central role in articulating a link between acting and the activities of the mind: is the notion of doxa. Since Heidegger, according to Arendt, never considers authenticity to the plural domain of appearance, doxa, understood first and foremost by him, as dokei, — "in appearing it gives itself an aspect," - would sustain neither authenticity nor truth. ${ }^{77}$ "Doxa is the regard <Ansehen, looking-at, esteem $>$ which every being conceals and discloses in its appearance <Aussehen> (eidos, idea)." Into the diversity of points of view, "the aspect $\langle$ Ansicht $\rangle$ is always one that we take and make for ourselves. In experiencing and dealing with beings, we are always forming views of their appearance." ${ }^{78}$ Departing from Heidegger's Dokeō, which means, "I show myself, appear, enter into the light" ${ }^{79}$ Arendt increasingly reviews doxa, leading it to a "strong connotation of the visible," $"$ and re-establishing the ontological constitutive power of opinion in the shape of it-appears-to-me, based on the twofold movement of seeing and being seen.

Arendt leads Heidegger's notion of truth as Un-verborgenheit "unconcealment" to the notion of opinion, doxa, borrowed from Socrates. It springs out a complete reversal on the concept of truth towards a phenomenality of the appearance — by what is disclosed as physis, [Schein] —, attained in the shape of opinion, doxa. Opinion is dokei moi, that what appears to me. "The assumption was that the world opens up differently to every man, according to his position in it; and that the 'sameness' of the world, its commonness (koinon, as the Greeks would say, common to all) or 'objectivity' (as we would say from the subjective view point of modern philosophy) resides in the fact that

77 HEIDEGGER. An Introduction to Metaphysics, p. 103 (Original, p. 78). In another passage: "Doxa means aspect, regarding $<$ Ansehen $>$, namely the regard in which one stands." Idem. Taminiaux underscores, contrary to Arendt, that by displaying aletheia through doxa, "what is thus unveiled, Heidegger insists, is threatened with being 'immediately covered over by opinion. Opinion crystallizes in positions that are repeated in such a way that what had been seen originally is veiled anew, covered over" (Heidegger, Sophist, p. 16). Hence the necessity of fighting against doxa." TAMINIAUX. The Thracian Maid and the Professional ThinkerArendt and Heidegger, p. 90.

78 HEIDEGGER. An Introduction to Metaphysics, p. 104 (Original, p. 79).

79 Ibidem, p. 103 (Original, p. 78).

80 (ARENDT. Philosophy and Politics, p. 94) It is undeniable that Arendt's theorization on doxa resounds Heidegger's reconstitution of the Greek manifold apprehensions of doxa - already in 1935's An Introduction to Metaphysics. In this latter, doxa is named for basically four accounts: "1) regard as glory; 2) regard as sheer vision that offers something; 3) regarding as mere looking-so: 'appearance' as mere semblance; 4) view that a man forms, opinion." HEIDEGGER. An Introduction to Metaphysics, p. 105. (Original, p. 79-80). It is important to mention that among Arendt's texts, there is not a consensual positive approach of opinion, and its relationship to truth. Philosophy and Politics is the substantial text where Arendt offers a positive account of opinion as doxa. In fact, as it will be seen in other sections, Arendt deals with doxa as opinion, as fame and glory, and as mere semblances as well. 
the same world opens up to everyone and that despite all differences between men and their positions in the world — and consequently their doxai (opinions) — both you and I are human." 81

By dealing with the value of appearance, one can most clearly distinguish Heidegger's metaphysical language being turned, by Arendt, into a sort of phenomenology of action and an ontological valuation of the surface. Going further on Heidegger's conception of appearance, one finds a semblance's face of appearance, that is, appearance as distortion, as illusion. In a different manner, one locates in Arendt's account of appearance as semblance as well, as it has been pointed out in this paper. What frees man from mere semblance in Arendt's account is permanency and consistence of the appearing image, - which, in other words, is constituted by opinion, and sustains a showing as well as a hiding feature. We are in a certain extent, responsible for what to show and what to hide. Astonishing enough, self-presentation also makes a case for lying.

Heidegger, on the contrary, mainly attributes perversion and distortion to opinion. ${ }^{82}$ As well formulated by Villa, he "creates a clear raking of authentic, wresting, 'bringing-into-the-light,' on the one hand, and the inauthentic, obscuring character of everyday opinion and discourse, on the other." 83 It is worth mentioning how Arendt, differing from Heidegger's conception, appropriates the pathos of doxa in the sense of appearance, - as the triumph of opinion - in order to positively enhance appearance. ${ }^{84}$

In the attempt to investigate the epistemology of appearance in Arendt, there are two main implications towards the ethics I try to articulate in this paper. First, by bestowing an ontological positive value of appearance, it can be upheld that appearance would be the accurate measure - instead of an invisible true self - for a visible consistent opinion and praxis. Appearance no longer sustains the same measure of inner truth merely turned into the realm of visibility; it instead gathers the power to conceal, asserting an affirmative account of concealment. "Yet, here again, we are not dealing with a sheer arbitrary error; the truth is, not only do appearances never reveal what lies beneath them of their own accord but also, generally speaking, they never just reveal; they also conceal." ${ }^{85}$ It is a matter of course that positively valuating

81 ARENDT. Philosophy and Politics, p. 80.

82 See HEIDEGGER. An Introduction to Metaphysics, p. 192. (Original, p. 165).

83 VILLA. Arendt and Heidegger - The Fate of the Political, p. 154.

84 Heidegger affirms that "The path now mentioned it that of doxa in the sense of appearance. Along this path the being looks now thus and now otherwise. Here only opinions prevail. Men slide back and forth from one opinion to another. They mix being and appearance." HEIDEGGER. An Introduction to Metaphysics, p. 112. (Original, p. 85).

85 ARENDT, LMT, p. 25. 
appearance would by no means lead to attribute appearing, speaking and acting with the same apparatus proper to inner truth, transposed to the realm of visibility. Through Arendt's account, the key point here is that ethics can no longer be raised in terms of what is to be a good person, but rather what is to act consistently and responsibly as a good person. ${ }^{86}$ Second, and consequently, by embracing a twofold meaning of revealing and concealing, truth as doxa, as uncovering, no longer leads to the cognitive adequation of the inner self, but rather to Arendt's most interpersonal dimension of men into the appearing world: who we are. ${ }^{87}$ Arendt's account on the visibility of the who based on the permanency and consistence of speech and acts, dislodges the ethical dimension from the inner good man towards the outward good citizen, necessarily visible among others in order to appear good to them.

\section{Time as Topos Noētos of Mind's Activities — "The Present Act of Attention"}

In the last topic, the place of temporality in the faculties of the mind will be elaborated. It is my claim that instead of spatial orientation as the 'active' of vita active, time transitions precisely into the topos, the place where the mind's activities occur. By positing memories and prospects, the mind is able to drive temporality, as much as, the activities of vita activa more directly drive spatiality. In The Human Condition, Arendt inaugurates her investigations concerning vita activa narrating one of the homo faber's conquests, the launching of the first man-made artificial satellite into the universe. In preservation and continuity as much as in creation and spontaneity, Arendt makes use of descriptive expressions privileging the location of human events, such as the space of appearance, private and public domains, the web of relationships and the polis. ${ }^{88}$ Regarding vita activa activities, spatiality is thus the more penetrating dimension. It is a worldly space where man labors, works, acts and creates. Action places its political activity par excellence. Even a closer

86 The Arendtian terminology appropriated to deal with ethics no longer fits into the usual way of addressing ethics, that means, in terms of which principles, whether universal or particular, define the good man. Though, the inescapable issue about which values guide our actions cannot be avoided. I will claim along this paper that the "self" of Arendt's mind activities is at the service of the who, a self which instead of concerning the good man, concerns the good citizen.

87 Through Husserl's account, Taminiaux has already paid attention to the evaluative feature of truth. "He [Husserl] had shown also that truth - more deeply than is entailed in its definition as adequation of, or correspondence between, intellect and thing - consists in every mode of intentionality exhibiting (aufweisen) its specific correlate." TAMINIAUX. The Thracian Maid and the Professional Thinker-Arendt and Heidegger, p. 39.

88 Cf. RICOEUR. Action, Story and History, p. 157. 
examination of the role of temporality in those spatial dimensions of vita activa, still takes place notwithstanding under spatial criteria. The animal laborans' temporal cycle of nature and its biological realm, the subsequent rupture of homo faber's world of artifacts bringing to the fore the temporal conditions of durability and enduring, and finally the unexpected and unpredictable praxis' realm of action, are all activities whose temporal dimensions - whether the realm of necessity whether the realm of freedom - are measured under the domain of spatiality, as bodily human movements can always be located. ${ }^{89}$

Regarding The Life of the Mind, Arendt resorts to a Kafkian parabola about time in order to illustrate the experience of suspending the linear and continuous temporality of the daily life proper of the activities of the mind. ${ }^{90}$ The insertion of man into such activities breaks the continuum, suspends the uninterrupted flux between past and future as successive dimensions and is therefore spatially impenetrable. ${ }^{91}$ In the time experience of mind's activities, the present would be the rupture, "a gap between past and future," "un présent qui dure," as Bergson states; or even, the medieval nunc stans. ${ }^{92}$ In mental activities the $\mathrm{He}$ from Kafka's parable would be metaphorically launched out of any topos noètos, any mental space, displacing the past-future binomial

89 See Taminiaux's accurate essay: Time and Inner Conflicts of the mind. In: HERMSEN; VILLA. (Ed.). The Judge and the Spectator- Hannah Arendt's Political Philosophy, p. 44. (Hereafter cited as "Time and Inner Conflicts of the mind")

90 Here I will take thinking activity in the sense of the mind's activities as a whole. Arendt quotes a parabola by Kafka, presented in a collection of aphorisms called 'HE': "He has two antagonists; the first presses him from behind, from his origin. The second blocks the road in front of him. He gives battle to both. Actually, the first supports him in his fight with the second, for he wants to push him forward, and in the same way the second supports him in his fight with the first, since he drives him back. But it is only theoretically so. For it is not only the two antagonists who are there, but he himself as well, and who really knows his intentions? His dream, thought, is that some time in an unguarded moment - and this, it must be admitted, would require a night darker than any night has ever been yet - he jump out of the fighting line and be promoted, on account of his experience in fighting, to the position of umpire over his antagonists in their fight with each other." (KAFKA. Gesammelte Schriften, v. V, p. 287. English translation by Willa e Edwin Muir. The Great Wall of China, p. 276-277) Cf. (ARENDT, LMT, p. 202).

91 Arendt makes a meaningful allusion to Bergson, who criticizes the terminology of spatial dimension applied to temporality, highlighting that temporality's terminology has being "borrowed from spatial language. If we want to reflect on time, it is space that responds.' Thus, 'duration is always expressed as extension,' and the past in understood as something lying behind us, the future as lying somewhere ahead of us." (ARENDT, $L M T$, p. 13) "This seeming spatiality of a temporal phenomenon is an error, caused by the metaphors we traditionally use in terminology dealing with the phenomenon of Time." Ibidem, p. 13.

92 Cf. Ibidem, p. 12. "Since time and space in ordinary experience cannot even be thought of without a continuum that stretches from the nearby into the distant, from the now into past or future, from here to any point in the compass, left and right, forward and backward, above and below, I could with some justification say that not only distances but also time and space themselves are abolished in the thinking process. As far as space is concerned, I know of no philosophical or metaphysical concept that could plausibly be related to this experience; but I am rather certain that the nunc stans, the 'standing now,' became the symbol of eternity the 'nunc aeternitatis' (Duns Scotus) - for medieval philosophy because it was a plausible description of experiences that took place in meditation as well as in contemplation, the two modes of thought known to Christianity." (Arendt, LMT, p. 86) 
from any spatial language of time. Past and future would be described as divided strengths "at the point where 'he' situates; and 'his' standpoint is not the present as we usually identify with, but a gap in time in which 'his' constant fighting, 'his' making a stand against past and future, keeps in existence."93 Present would be a "lasting todayness," amalgamating the spatiality of time, in which the taken of position of each new individual drives and places his past and future, those dimensions of "no more" and "not yet".

By despatializing the topos of mental life, what is crucial for us here is the human's capacity to take a position, driving and placing 'past' through remembrance and future through expectation. Time turns precisely into the topos, the place where the mind's activities happen to be. By positing memories and prospects the mind is able to drive temporality. "The time continuum, everlasting change, is broken up into the tenses past, present, future, whereby past and future are antagonistic to each other as the no-longer and the not-yet only because of the presence of man, who himself has an 'origin,' his birth, and an end, his death, and therefore stands at any given moment between them; this in-between is called the present. It is the insertion of man with his limited life span that transforms the continuously flowing stream of change ... into time as we know it."94 Such insertion of man reverberates Arendt's approach on Augustine's distinction between principium of the world and initium of man, as much as, in his considerations regarding the notion of time in Confessions.

The world of all living creatures other than man were created "in numbers" and cycles, corresponding with the Fabrica Dei. Since man seals his initium by uniqueness, the very reason he is inserted into this in-between present, the scope to which he keeps his position in the world breaks up the continuum. "It is this insertion - the beginning of a beginning, to put it into Augustinian terms - which splits up the time continuum into forces which then, because they are focused on the particle or body that gives them their direction, being fighting with each other and acting upon man is the way Kafka describes." 95 Time is defined here by the nature of man's activities. In the everyday of animal laborans and homo faber occupations, inasmuch as what takes place is "the continuity of our business and our activities in the world in which we continue what we started yesterday and hope to finish tomorrow", this continuum

\footnotetext{
93 ARENDT. Between Past and Future - Eight Exercises in Political Thought, p. 11. (Hereafter quoted as ARENDT, BPF).

94 (ARENDT, LMT, p. 203) See: BAZZICALUPO. II present come tempo della politica in Hannah Arendt, p. 139168.

95 ARENDT, BPF, p. 11
} 
determines, and conditions time towards spatial measurements, more conditioned to encircling linear time states ${ }^{96}$ It is precisely in such terms that the time of our historical and biographical everyday life can be "understood in analogy to numerical sequences, fixed by the calendar, according to which the present is today, the past begins yesterday, and the future begins tomorrow." ${ }^{97}$

In the Confessions, the philosopher Hippo has coined a remarkable expression to illustrate time, namely, "a present act of attention." It is meaningful for me at this point not only in order to relocate the three time dimensions through the act of attention, on the past through memory, and on the future through expectation. It is even more important, inasmuch as the present constitutes the act in itself of our attention towards one of both directions, and the present cannot be measured as a time tense, since there is no mind's time tense between what just happened and what will happen a minute later. The present act of attention can only be described then as the human capacity of choice, of driving the mind's attention. Rather than three time tenses spatially located as a past of "behind" and a future "ahead," time concerning the activities of the mind is made present, "the present of things past is memory, the present of things present is sight, the present of things future is expectation." 98 Augustine illustrates: "Suppose that I am about to recite a psalm that I know. Before I begin, my expectation is directed to the whole of it; but when I have begun, so much of it as I pluck off and drop away into the past becomes matter for my memory, and whole energy of the action is divided between my memory, in regard to what I have said, and my expectation, in regard to what I am still to say. But there is a present act of attention, by which what was future passes on its way to becoming past. The further I go in my recitation, the more my expectation is diminished and my memory lengthened, until the whole of my expectation is used up when the action is completed and has passed wholly into my memory." 99

In The Human Condition's terminology, Arendt's “subjective inbetween" 100 is linked to this mind's ability of an in-between present. In terms of mind's activities, what takes place is an urgency for location which is found in the gap between the linear past and future tenses. The present act of attention of whose invisible activities implies a fundamental presupposing of taking a

\footnotetext{
96 ARENDT, LMT, p. 205

97 Idem.

98 AUGUSTINE, Confessions. (Book Eleven, XX, p. 223). (Hereafter cited as Confessions)

99 Augustine adds: "Indeed it is the same for the whole file of man, of which all a man's actions are parts." Augustine, Ibidem. (Book Eleven, XXVIII, p. 230)

100 See in The Human Condition Arendt's distinction between an objective and a subjective in-between.
} 
position, a position that is dependent on a search for meaning, "to assume the position of 'umpire,' of arbiter and judge over the manifold, never-ending affairs of human existence in the world, never arriving at a final solution to their riddles but ready with ever-new answers to the question of what it may be all about." 101

To take a position has two meanings. Firstly, the mind's ability to place time occurs through the measure of a beginning and an end of what the mind brings into presence. This means the human being's capacity of establishing a present to himself. ${ }^{102}$ Secondly, by attributing to the activities of the mind a capacity of breaking with a straight-line trilogy of time, we have another way of describing a dismantling of the metaphysical tradition. It destroys neither the necessary past, nor the unpredictable future. It confines man, through the activities of the mind, in each new situation, toward the responsibility to relocate himself, which like all experience in doing something, only takes place through practice and exercise.

The space where the acting man - the Achilles from The Human Condition - , creates and acts, and the time where the Kafkian $H E$ places himself, are woven in the in-between space in the Arendtian agora. Thus, contrary to some Arendtian interpreters - who asseverate the absolute gap between the life of the mind and the notions of ethics, action, and responsibility - I believe that even if it is not possible to completely fulfill the gap between the world and the self — between vita activa and vita contemplativa - , ethics can take a forward step on the path of reconciliation between the self and the world.

\section{Bibliography}

ARENDT, Hannah, Love and Saint Augustine. Edited and with an Interpretive Essay by Joanna Vechiarelli Scott and Judith Chelius Stark. Chicago/London: The University of Chicago Press, 1996 (Der Liebesbegriff bei Augustin. Berlin: J. Springer, 1929. Hannah Arendt's Papers, The Manuscript Division, Library of Congress, 033082, container 72).

. Philosophy and Politics. Social Research, v.57, n.1, p. 73-103, Spring 1990. . The Life of Mind - One/Thinking, Two/Willing. New York/London:

Harvest/HJB Book, 1978.

101 ARENDT, LMT, p. 210.

102 In The Life of the Mind, Arendt emphasizes: "Time that can be measured is in the mind itself; namely, 'from the time I began to see until I cease to see.' For 'we measure in fact the interval from some beginning up to some kind of end,' and this is possible only because the mind retains in its own present the expectation of that which is not yet, which it then 'pays attention to and remembers when it passes through." (LMW, $p$. 107) See: BIRULÉS. Poetica e politica. Hannah Arendt, Abitare il present, p. 45-62. 
. Basic Moral Propositions. Unpublished manuscript from 1966. ARENDT, Hannah. Basic Moral Propositions. Lectures 1966, University of Chicago, Hannah Arendt's Papers, The Manuscript Division, Library of Congress, Washington, D.C., container 46.

. Truth and Politics. In: . Between Past and Future - Eight Exercises

in Political Thought. New York: The Penguin Books, 1977, p. 235 . Between Past and Future - Eight Exercises in Political Thought. New York: The Penguin Books, first edition 1961, 1977.

. The Human Condition, Chicago-London: The University of Chicago Press, 1989. (First Edition 1958).

AUGUSTINE. Confessions. Translated by F.J. Sheed, and introduction by Peter Brown. Indianalopolis/Cambridge: Heckett Publishing Company Inc., 1993.

BAKAN, Mildred. Arendt and Heidegger: the episodic Intertwining of Life and Work. Philosophy \& Social Criticism, v. 12, n. 1, p. 71-98, Spring 1987.

BAZZICALUPO, L. Il present come tempo della politica in Hannah Arendt. In: PARISE, Eugenia (Ed). La Politica tra Natalità e Mortalita — Hannah Arendt. Napoli: Edizioni Scientifiche Italiane, 1993. p. 139-168.

BENHABIB, Seyla. The Reluctant Modernism of Hannah Arendt. London/New Delhi: Sage Publications, 1996.

BERNSTEIN, Richard J. Provocation and Appropriation: Hannah Arendt's Response to Martin Heidegger. Constellations, v. 4, n. 2, p. 153-171, 1997.

BERGSON, Henri. Matière et Mémoire. In: . Euvres. Édition du Centenaire. Introduction par Henri Gouhier, 6e éd. Paris: Presses Universitaires de France, 2001. BIRULÉS, F. Poetica e politica. Hannah Arendt, Abitare il present. In: PARISE, Eugenia (Ed). La Politica tra Natalità e Mortalita - Hannah Arendt. Napoli: Edizioni Scientifiche Italiane, 1993. p. 45-62.

CURTIS, Kimberley. Aesthetic Foundations of Democratic Politics in the Work of Hannah Arendt. In: CALHOUN, Craig. (Ed.). Hannah Arendt and the Meaning of Politics. Minnesota: University of Minnesota Press, 1997. p. 27-52

FISTETTI, Francisco. Hannah Arendt e Martin Heidegger - Alle origini della filosofia occidentale. Roma: Editori Riuniti, 1998.

GIUSTI, Roberto. Antropologia della Libertà - A comunità delle singolarità in Hannah Arendt. Assisi: Cittadella Editrice, 1999.

GROSSMANN, Andreas, "Im anfang liegt alls beschlossen": Hannah Arendts politisches Denken im Schatten eines Heideggerschen problems. Man and World, v. 30, p. 35-47, 1997.

HEIDEGGER, Martin. Plato's Sophist. Translated by Richard Rojcewicz and André Schuwer. Bloomington/Indianapolis: Indiana University Press, 1997. (Published in German as Platon: Sophistes. Frankfurt am Main: Vittorio Klostermann, 1992).

. An Introduction to Metaphysics. Translated by Ralph Manheim. New Haven/ London: Yale University Press, 1987. (Published in German as Einführung in die Metaphysik. Tübingen: Max Niemeyer Verlag, 1966). 
. Being and Time. Translated by John Macquarrie \& Edwards Robinson. New York: Harper \& Row, 1962 (Published in German as Sein und Zeit. 17 $7^{\text {th }}$ ed. Tübingen: Max Niemayer Verlag, 1993).

HONNETH, Axel. Invisibility: On the Epistemology of "Recognition”. Unsichtbarkeit - Über die Moralische Epistemologie von >Anerkennung<. In

Unsichtbarkeit - Stationen einer Theorie der Intersubjektivität. Frankfurt: Suhrkamp, 2003.

KAFKA, Franz. Gesammelte Schriften. New York: [s.n.], 1946. v. V, p. 287. (English translation by Willa e Edwin Muir. The Great Wall of China. New York: [s.n.], 1946. p. 276-277)

ØVERENGET, Einar. Heidegger and Arendt: Against the Imperialism of Privacy. Philosophy Today, v. 39, n. 4/4, p. 430-444, Winter 1995.

PAREKH, Bhikhu. Hannah Arendt and The Search for a New Political. London: Macmillan, 1981.

RICOEUR, Paul. Action, Story and History. In: GARNER, Reuben. The Realm of Humanities - Responses to the Writings of Hannah Arendt. New York: Peter Lang, 1990. p. 149-164.

SAVARINO, Luca. "Quaestio mihi factus sum" - una lettura heideggeriana dil il concetto d'amore in Agostino. In: . Hannah Arendt, introduzione e cura di Simona Forti. Millano: Bruno Mondadori, 1999. p. 249-269.

TAMINIAUX, Jacques. Time and Inner Conflicts of the Mind. In: HERMSEN, Joke; VILLA, Dana (Ed.). The Judge and the Spectator- Hannah Arendt's Political Philosophy. Leuven: Peeters, 1999. p. 43-58.

. The Thracian Maid and the Professional Thinker - Arendt and Heidegger. Translated and edited by Michael Gendre, Albany: State University of New York Press, 1997. (Published in French as La Fille de Thrace et le Penseur Professionnel-Arendt et Heidegger. Paris: Éditions Payot, 1992).

. Le paradoxe de l'appartenance et du retrait. In: COLLIN, Françoise (Ed.). Politique et Pensée - Colloque Hannah Arendt. Paris: Éditions Payot \& Rivages, 1996. p. 95-112.

TASSIN, Étienne. Virtuosité de l'action, vérité de l'apparence. In: Le Trésor Perdu - Hannah Arendt, L'Intelligence de L'Action Politique. Paris: Éditions Payot \& Rivages, 1999.

. La question de l'apparence. In: COLLIN, Françoise (Ed.). Politique et Pensée - Colloque Hannah Arendt. Paris: Éditions Payot \& Rivages, 1996. p. 69-94. VILLA, Dana. Arendt and Heidegger — The Fate of the Political. Princeton/New Jersey: Princeton University Press, 1996. 